\title{
Performance of NiO/YSZ anode-supported solid oxide fuel cell fueled with landfill gas stream
}

\author{
Cevat Yaman ${ }^{1, *}$, and Yusuf Kucukaga ${ }^{2}$ \\ ${ }^{1}$ Imam Abdulrahman Bin Faisal University, Environmental Engineering Department, Dammam, 19082, Saudi Arabia \\ ${ }^{2}$ Gebze Technical University, Environmental Engineering Department, Kocaeli, 41400, Turkey
}

\begin{abstract}
Generating electrical energy from landfill gas (LFG) is a challenge due to its low conversion efficiency. In this study, performance of a $\mathrm{NiO} /$ yttria-stabilized zirconia (NiO-YSZ) anode-supported cell operating with LFG feed stream was evaluated. This study investigated the potential of solid oxide fuel cells (SOFC) to produce electricity from LFG generated in pilot scale anaerobic municipal solid waste bioreactors. During the initial experiments, power generation was achieved in the SOFC with direct feeding of the LFG. Different feed flow rates $(10-25 \mathrm{~mL} / \mathrm{min})$ and varying temperature conditions $\left(700-800{ }^{\circ} \mathrm{C}\right)$ were also investigated to define the optimal conditions. Experiments were carried out at different feed rates and the successful results obtained from $10 \mathrm{~mL} / \mathrm{min}$ and $20 \mathrm{~mL} / \mathrm{min}$ feed speeds. It was also observed that the maximal power values were between $0.10-0.11 \mathrm{Watt} / \mathrm{cm}^{2}$ for all experiments. This study showed that SOFCs can provide significantly higher energy efficiencies than steam engines for LFG conversion into electrical energy.
\end{abstract}

\section{Introduction}

At conventional waste disposal sites, the aim is both to benefit economically from the landfill and re-open the landfill area at the earliest for beneficial use by eliminating the environmental risks. In a closed landfill, the landfill should be monitored by recirculating the leachate back to the waste mass until all the toxic compounds that are harmful to the environment are completely removed. This is possible if the landfill is operated as a landfill bioreactor. Landfill bioreactors increase the moisture content of the waste, thus the waste is decomposed and stabilized faster. The moisture is usually supplied from the leachate produced in the landfill. By recirculating of leachate, water content, nutrients, enzymes and the bacteria are evenly distributed in the landfill. Landfill gas production will increase, and economic benefit will be gained because landfill bioreactors accelerate the decomposition and the stabilization.

Today, the two most important issues related to energy systems are energy efficiency and environmentally friendly energy production with low emission values. These justifications necessitate the use of a high efficiency technology in electricity generation and transmission. Solid Oxide Fuel Cells (SOFC), which generate electrical energy from hydrocarbons with about $70 \%$ efficiency, are among the most important technologies to be used in the future with various design and mechanical improvements. The SOFC systems have higher energy efficiency than the other types of fuel cells (up to $85 \%$ with the use of heat released during energy production). These systems are environmentally friendly especially with very low emissions and very quiet operation.

Fuel cells, which are also called electrochemical energy converters, generate electricity and heat through electrochemical reactions by combining gas fuel with an oxidizing gas through an ion-conducting electrolyte. Their efficiency is higher than conventional internal combustion conversions and they produce very little emissions. The difference between the fuel cells of many types depends on the materials used such as electrolyte, anode, cathode and the temperature of use.

The main advantage is the flexibility of the fuel. A variety of biofuels with natural gas, alcohol and hydrocarbons can be used. Fuel cells release electrons, protons, energy and water by using a specific fuel such as hydrogen, methane, methanol, and natural gas. There is no direct combustion in fuel cells. Simply a fuel cell operating principle is based on a simple oxidationreduction reaction as given in the following equation (Eq. 1).

$$
\mathrm{H}_{2}+\mathrm{O}^{-2} \rightarrow \mathrm{H}_{2} \mathrm{O}+2 e^{-}
$$

In this reaction, unlike direct combustion, electrons are switched on in a regular and controlled manner, while oxygen ions are passed through a membrane called permeable ions but not permeable to molecules or metal ions. Generally, fuel cells are composed of membranes, such as electrolytes and electrodes. In these electrodes, oxygen and fuel are ionized to produce electrons and water, and oxygen ions are transmitted through the electrolyte while electrons are transmitted through current collectors. The wider the surface of the electrodes, the more they show catalytic activity. Therefore, it is very

* Corresponding author: cyaman@iau.edu.sa 
important that the surface area of the electrodes is high. Because the oxygen ions move in the membrane (the electrolyte), the shorter the distance between the electrodes, the lower the resistance across the electrolyte. The high-porosity electrodes and the fuel cell, which consist of a finely stable electrolyte, help to achieve optimum values for high energy. Various reactions take place on the anode and cathode sides of solid oxide fuel cells. These reactions produce different stresses in these regions. The difference between these voltages makes it possible to use solid oxide fuel cells as a battery. The reactions taking place at the anode and cathode are as follows (Eq. 2 through 7).

$$
\begin{gathered}
\mathrm{H}_{2}+\mathrm{O}^{-2} \rightarrow \mathrm{H}_{2} \mathrm{O}+2 e^{-} \text {(Anode) } \\
\mathrm{CO}+\mathrm{O}^{-2} \rightarrow \mathrm{CO}_{2}+2 e^{-} \text {(Anode) } \\
\mathrm{CH}_{4}+4 \mathrm{O}^{-2} \rightarrow \mathrm{CO}_{2}+2 \mathrm{H}_{2} \mathrm{O}+8 e^{-} \text {(Anode) } \\
1 / 2 \mathrm{O}_{2}+2 e^{-} \rightarrow \mathrm{O}^{-2}(\text { Cathode }) \\
\mathrm{CO}+\mathrm{H}_{2} \mathrm{O} \rightarrow \mathrm{H}_{2}+\mathrm{CO}_{2} \text { (Anode) } \\
\mathrm{CH}_{4}+\mathrm{H}_{2} \mathrm{O} \rightarrow 3 \mathrm{H}_{2}+\mathrm{CO} \text { (Anode) }
\end{gathered}
$$

The anode portion of the solid oxide fuel cell is supplied with pure hydrogen, hydrocarbons (gasoline, natural gas $-\mathrm{CH}_{4}$ ) or alcohols as fuel. These fuels undergo a processing step to obtain molecules used in the fuel cell for reactions in equations (2), (3) and (4), such as $\mathrm{H}_{2}, \mathrm{CO}$ and $\mathrm{CH}_{4}$. Equations (3) and (4) don't really occur because the equations (6) and (7) are realized much faster. If the equation (3) is realized, carbon monoxide $(\mathrm{CO})$ in the hydrogen gas is also used as fuel, but if the equation (6) is realized, this $\mathrm{CO}$ provides $\mathrm{H}_{2}$ from water and is used as fuel. The same applies to methane $\left(\mathrm{CH}_{4}\right)$. The cathode side is supplied with oxygen or another gas such as oxygen-containing air.

There are several advantages of solid oxide fuel cells. For instance, fuel processing and desulphurization are improved due to thermal compatibility. Another advantage of fuel cell is that less cell sintering is required when preparing cell materials and time-dependent deformation is reduced, thus increasing the geometric tolerances. Furthermore, less thermal stresses occur at low temperatures, which will reduce the resistance density of the fuel cell. A wide variety of alternatives are provided for the insulating layers used for sealing in the fuel cell.

Today, fuel cells are one of the most important elements for the widespread use of hydrogen energy and other clean and renewable energy sources. Fuel cells are an electrochemical device that directly converts chemical energy into electrical energy and releases heat only as a by-product. Compared to conventional energy converters, fuel cells have superior features such as high efficiency, reliability, modularity, and noise-free operation. Since it generates both electrical energy and heat, SOFC systems can meet all the electricity needs of a house while meeting the heating and cooling needs. While the efficiency in current energy systems is $30-40 \%$, it can reach $90 \%$ in low temperature solid oxide fuel cells. Recently, the SOFC market has been growing significantly [1-8]. Fig. 1 shows a typical solid oxide fuel cell [9].
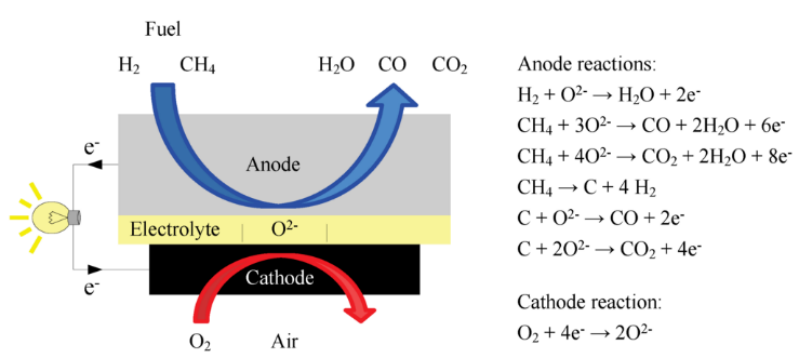

Fig. 1. A typical methane-fed solid oxide fuel cell [9].

As one of the hydrocarbon fuels, $\mathrm{CH}_{4}$ is the main component of natural gas, which can be used directly in SOFCs. Previous studies have shown that when $\mathrm{CH}_{4}$ is used as fuel, several chemical and electrochemical reactions occur on the anode side of the fuel cell [10-12]. The result of these reactions consists of six species, which are deposited carbon $(\mathrm{C}), \mathrm{H}_{2}, \mathrm{CO}, \mathrm{CO}_{2}, \mathrm{H}_{2} \mathrm{O}$ and residual $\mathrm{CH}_{4}$. A probable reaction in the anode is methane decomposition (Eq. (8)):

$$
\mathrm{CH}_{4} \rightarrow \mathrm{C}+2 \mathrm{H}_{2}
$$

Removal of carbon using $\mathrm{H}_{2}$ gas was studied in detail by several authors. It was reported that the separation of surface carbon from Ni/yttria-stabilized zirconia (Ni-YSZ) causes less damage to the Ni-YSZ structure compared to removal of carbon with oxygen [13]. One study investigated the carbon gasification with $\mathrm{H}_{2}$ in a $\mathrm{Ni}$-YSZ cell and concluded that the gasification rate varied greatly depending on the $\mathrm{H}_{2}$ concentration [14]. Pure $\mathrm{H}_{2}$ gas was observed to completely gasify the carbon on the surface of the cell.

Cell stability is an important criterion for SOFC working with hydrocarbon-based fuels. Tao et al. [15] added an additional functional $\mathrm{Ce}_{1-\mathrm{x}} \mathrm{Ni}_{\mathrm{x}} \mathrm{O}_{2-\mathrm{y}}$ layer to enhance Ni-SDC (nickel samaria-doped ceria) cell stability using hydrocarbon fuels. This cell exhibited resistance to carbon deposition and showed a partially stable open circuit voltage with $0.8 \%$ degradation with dry ethanol.

Landfill gas (LFG) is a product of anaerobic degradation and mainly consists of methane $\left(\mathrm{CH}_{4}\right)$ and carbon dioxide $\left(\mathrm{CO}_{2}\right)$. Thus, $\mathrm{LFG}$ is known as a renewable energy source. Waste-to-energy is a well-known concept for landfill sites; however, the high energy content of LFG is typically converted to electricity by using gas engines. This phenomenon has been proved as a low efficient process and has many problems, such as siloxane contamination inside the engine.

The LFG produced in this study is used in the production of electricity with modular and high technology fuel cell systems which are completely environment friendly and produce water vapor only as an end-product. Within the scope of this study, this will be a unique study on converting landfill gas into electrical energy with fuel cells instead of using steam engines. In this study, LFG from a pilot scale anaerobic landfill bioreactor, which contains $900 \mathrm{~kg}$ of municipal solid 
waste (MSW), was used as energy source for a solid oxide fuel cell.

\section{Methodology}

\subsection{Theoretical background}

The energy conversion efficiency of the fuel cells is not limited to Carnot efficiency and can reach up to $90 \%$ with the combined heat and power system. One of the expressions of efficiency for fuel cells is theoretical efficiency. Theoretical efficiency is the expression of the maximum efficiency a fuel cell can achieve and is expressed as follows [16] (Eq. 9):

$$
e_{\text {ideal }}=\frac{\Delta G}{\Delta H}=1-T \frac{\Delta S}{\Delta H}
$$

where, $\Delta G, \Delta H$ and $\Delta S$ represent Gibbs free energy, enthalpy and entropy, respectively. Assuming that all Gibbs free energy is converted to electricity for fuel cells, the maximum possible theoretical efficiency can be calculated as follows (Eq. 10):

$$
e_{\text {ideal }}=\frac{\Delta G}{\Delta H}=\frac{237.34 \mathrm{kj} . \mathrm{kg}^{-1}}{286.02 \mathrm{kj}_{\mathrm{kg}} \mathrm{kg}^{-1}}=83 \%
$$

Generally, the lower thermal value of hydrogen is used in theoretical fuel cell efficiency calculations. Thus, the yield is more than $83 \%$. The purpose of this here is not to increase the efficiency numerically, but to compare it with internal combustion engines (Eq. 11).

$$
e_{\text {ideal }}=\frac{\Delta G}{\Delta H_{\text {lowerheat }}}=\frac{228.74 \mathrm{kj} . \mathrm{kg}^{-1}}{241.98 \mathrm{kj} . \mathrm{kg}^{-1}}=94.5 \%
$$

In fuel cells, cell potential decreases during operation due to polarizations. Therefore, the net yield depends on the cell potential $V_{\text {cell }}$. The voltage efficiency can be defined as follows (Eq. 12):

$$
e_{\text {voltage }}=\frac{V_{\text {cell }}}{V_{\max }}
$$

where, $V_{\max }$ is the Nernst potential, or the maximum voltage potential, and $V_{\text {cell }}$ is the actual cell potential.

Another efficiency expression in fuel cells is called fuel usage efficiency. Fuel utilization is an expression of how much fuel and oxidant is supplied to the system during conversion. Under actual operating conditions, not all fuel sent to the fuel cell can be converted into energy. In this case, the fuel and some of the oxidant supplied to the system leave the fuel cell before it converts into energy. Accordingly, fuel use is expressed as the ratio of the fuel flow corresponding to the electrical current generated in the system to the actual fuel flow sent to generate the same current.

Three different efficiencies are expressed for fuel cells. These efficiency statements affect the overall operating status of the fuel cell. Therefore, the actual efficiency of the fuel cell is equal to the three efficiency expressions, the theoretical efficiency, the voltage efficiency, and the multiplication of the fuel usage efficiency (Eq. 13).

$$
e_{\text {real }}=e_{\text {ideal }} \cdot e_{\text {voltage }} \cdot e_{\text {usage }}
$$

The stoichiometric ratio, which is the inverse of faradic efficiency, is defined for fuel cells. Stoichiometric ratio is a type of expression that is often used to prevent excess oxidant from being sent during the electrochemical reaction (Eq. 14 and Eq. 15):

$$
\begin{aligned}
& \lambda_{c}=\frac{1}{\varepsilon_{c}} \\
& \lambda_{a}=\frac{1}{\varepsilon_{a}}
\end{aligned}
$$

Anode and cathode stoichiometry for fuel cells is usually more than 1 . In other words, more fuel and oxidant are provided above $100 \%$ fuel usage value. In the literature, stoichiometric ratio of hydrogen is between 1.2 and 2, while air stoichiometry ranges between 1.5 and 4 . In addition, there are many misleading data in the literature regarding fuel efficiency. Fuel usage efficiencies vary according to the flow rate and fuel cell operating voltage [16].

\subsection{Design of LFG-SOFC system}

LFG was collected from the pilot scale landfill bioreactor (LBR) to a flexible gas sampling bag. Then it was slightly pressurized to sustain a constant flow during the SOFC energy conversion experiment. Inlet flow of LFG was controlled with a gas flowmeter, and different flow rates were investigated to identify the maximal current produced in the SOFC system. Solid oxide fuel cells were first reduced with hydrogen gas to allow nickel oxidenickel conversion. Then, when the operating temperature reached $775{ }^{\circ} \mathrm{C}$, the input $\mathrm{LFG}$ was fed into the fuel cell at different speeds $(10-20 \mathrm{~mL} / \mathrm{min})$. The gas balloon was gently pressurized and fed at constant speed with the help of rotameter. During SOFC experiments, voltage, power and current values were recorded instantaneously on computer assisted system in order to monitor the efficiency of energy obtained from LFG.

Anode supported micro tubular solid oxide fuel cells were used in this study. The cells were developed in a nanotechnology laboratory. Anode electrolyte and cathode materials were NiO-YSZ (50/50, weight/weight) composite powder, 8YSZ $\left(\% 8 \mathrm{Y}_{2} \mathrm{O}_{3}\right.$ doped with $\left.\mathrm{ZrO}_{2}\right)$ and LSM (lanthanum strontium manganite), respectively. Anode support layers were prepared via thermoplastic extrusion. The active surface of cathode was $3 \mathrm{~cm}^{2}$.

The composition of LFG produced from pilot scale anaerobic bioreactors was measured by Agilent $6890 \mathrm{~N}$ gas retention detector gas chromatography (GC-TCD). In GC-TCD analysis, Agilent HP-PLOT/Q model capillary column was used for $\mathrm{CO}_{2}$ capture and Agilent HPMOLSIEVE capillary column was used for separation of other gases. Detailed content of LFG used in this study is presented in Table 1. To determine the energy conversion efficiency of the SOFC experiment, voltage, power and current were recorded during the experiment by computer-based control system (Fig. 2). 
Table 1. LFG content used in SOFC experiments

\begin{tabular}{lll}
\hline Gas & Unit & Value \\
\hline $\mathrm{CH}_{4}$ & $\%$ & 51,04 \\
$\mathrm{CO}_{2}$ & $\%$ & 27,48 \\
$\mathrm{~N}_{2}$ & $\%$ & 12,68 \\
$\mathrm{O}_{2}$ & $\%$ & 3,53 \\
$\mathrm{Others}$ & $\%$ & 5,27 \\
$\mathrm{H}_{2} \mathrm{~S}$ & ppm & 1105 \\
\hline
\end{tabular}

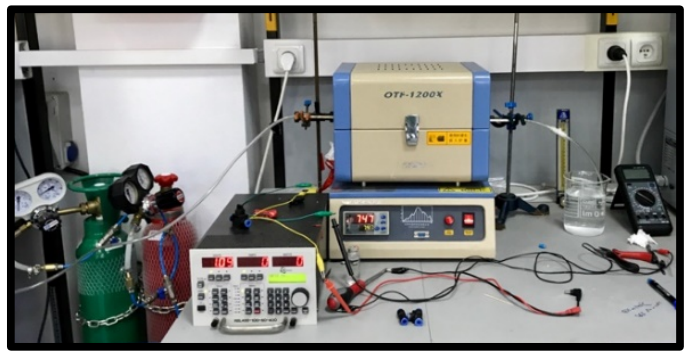

Fig. 2. Experimental set up with fuel cell.

\section{Results}

LFG is a mixture of gas with high energy value, which mainly contains $\mathrm{CO}_{2}$ and $\mathrm{CH}_{4}$ produced by anaerobic biodegradation of organics in landfills. LFG is converted into electrical energy with very low efficiency (30-40\%) by conventional internal combustion gas engines. Producing electrical energy from chemical energy with an efficiency of approximately $60 \%$ from hydrocarbons, SOFCs will be among the most important energy conversion technologies to be used in the future.

The current-voltage (i-V) and the corresponding power density current density figures when the SOFC is fueled with pure $\mathrm{CH}_{4}$ and landfill gas are shown in Fig. 3 and Fig. 4, respectively. The open circuit voltage (OCV) values for the Ni-YSZ cells at $775{ }^{\circ} \mathrm{C}$ were measured as $0.42-0.90 \mathrm{~V}$ with pure methane as the fuel and 0.21$1.00 \mathrm{~V}$ with landfill gas as the fuel with feeding speed of $20 \mathrm{~mL} / \mathrm{min}$ and $0.14-0.98 \mathrm{~V}$ with feeding speed of $10 \mathrm{~mL} / \mathrm{min}$ (Fig. 3 and Fig. 4). The open circuit voltage values for the Ni-YSZ cells at $750{ }^{\circ} \mathrm{C}$ were measured as 0.09-0.97 $\mathrm{V}$ with landfill gas as the fuel with feeding speed of $15 \mathrm{~mL} / \mathrm{min}$ and $0.08-0.98 \mathrm{~V}$ with feeding speed of $20 \mathrm{~mL} / \mathrm{min}$ (Fig. 5).

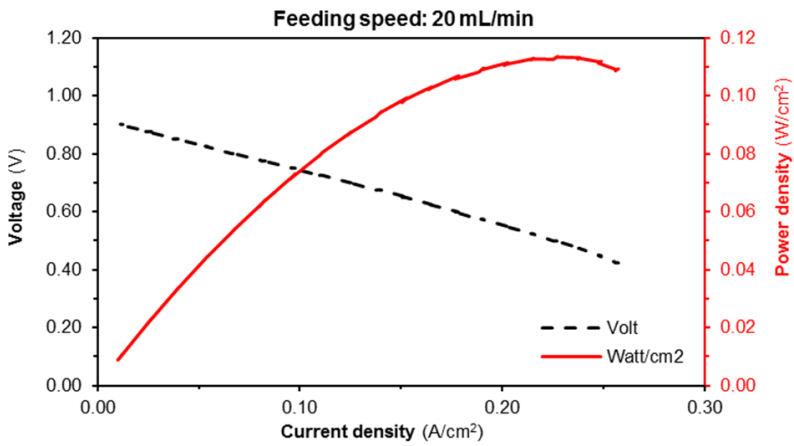

Fig. 3. Electricity production from pure methane gas with fuel cell with feeding speed of $20 \mathrm{~mL} / \mathrm{min}$ at $650{ }^{\circ} \mathrm{C}$.
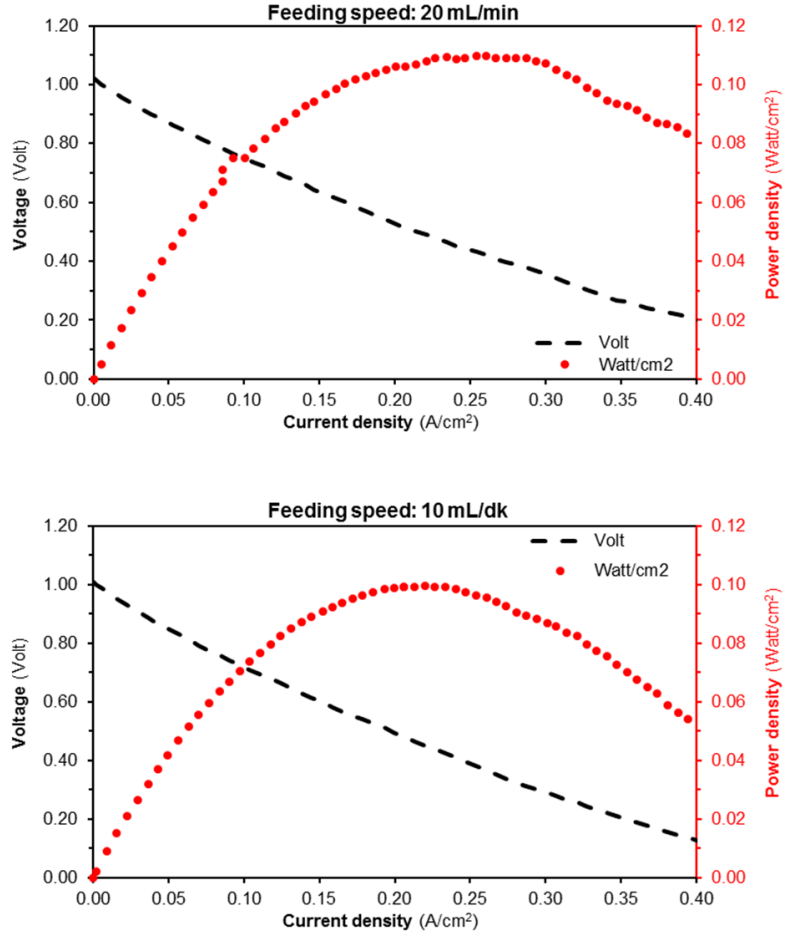

Fig. 4. Electricity generation from LFG with fuel cell with feeding speed of $10 \mathrm{~mL} / \mathrm{min}$ and $20 \mathrm{~mL} / \mathrm{min}$ at $775^{\circ} \mathrm{C}$.
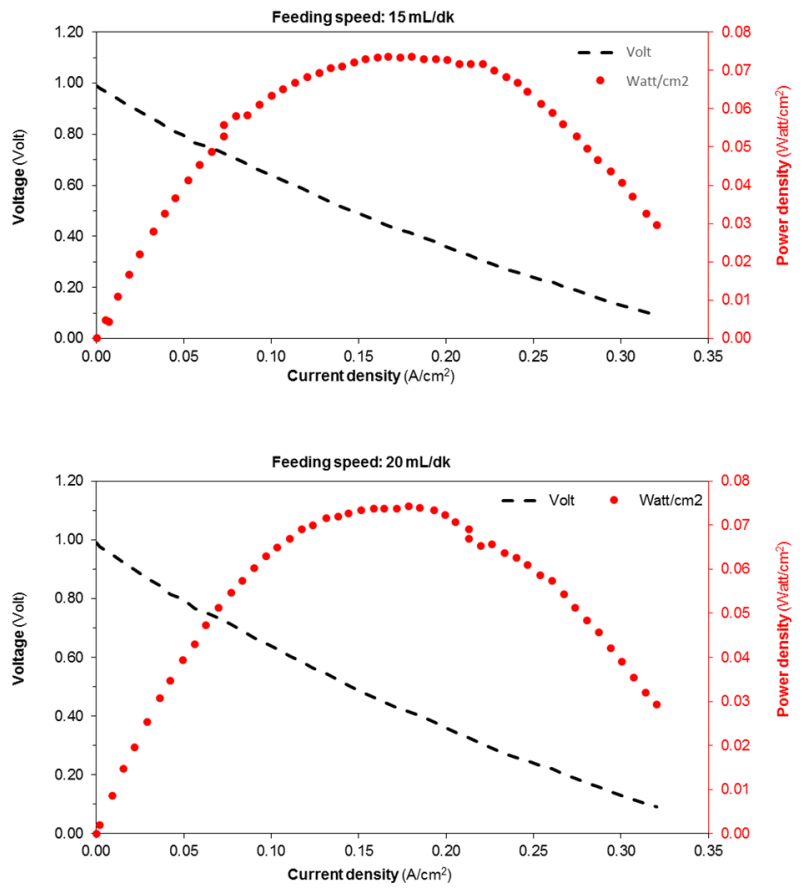

Fig. 5. Electricity generation from $L F G$ with fuel cell with $15 \mathrm{~mL} / \mathrm{min}$ and $20 \mathrm{~mL} / \mathrm{min}$ at $750{ }^{\circ} \mathrm{C}$.

Experiments were carried out at different feed rates and the successful results obtained from $10 \mathrm{~mL} / \mathrm{min}$ and $20 \mathrm{~mL} / \mathrm{min}$ feed speeds and the results of the pre-test performed with pure methane gas at $650{ }^{\circ} \mathrm{C}$ were compared in Table 2. It was also observed that the maximal power values were between $0.10-0.11 \mathrm{Watt} / \mathrm{cm}^{2}$ for all experiments. It can be seen from Fig 3, Fig 4, and Fig 5 that the highest power densities for the Ni-YSZ cells were achieved at the highest temperature of $775^{\circ} \mathrm{C}$ tested. 
Table 2. Electrical voltage, current and power values obtained from SOFC experiments at $775^{\circ} \mathrm{C}$.

\begin{tabular}{|c|c|c|c|c|c|}
\hline 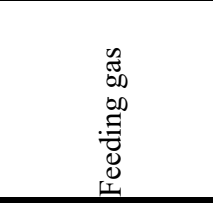 & 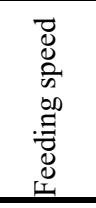 & 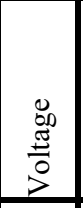 & 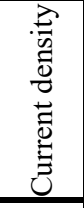 & 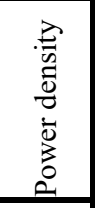 & 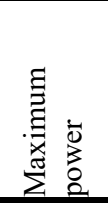 \\
\hline & $\mathrm{mL} / \mathrm{m}$ & Volt & $\mathrm{A} / \mathrm{cm}^{2}$ & $\mathrm{~W} / \mathrm{cm}^{2}$ & $\mathrm{~W} / \mathrm{cm}^{2}$ \\
\hline$\% 100 \mathrm{CH}_{4}$ & 20 & 0,700 & 0,125 & 0,088 & 0,114 \\
\hline LFG $\left(\% 51 \mathrm{CH}_{4}\right)$ & 20 & 0,705 & 0,121 & 0,085 & 0,110 \\
\hline LFG $\left(\% 51 \mathrm{CH}_{4}\right)$ & 10 & 0,709 & 0,104 & 0,074 & 0,099 \\
\hline
\end{tabular}

\section{Discussion}

Fuel cells are an efficient, combustion-free, virtually pollution-free power source for a green energy production that is perfectly environment-friendly, completely silent and has a few moving parts. The desire for solid oxide fuel cells to be manufactured at larger sizes, with more power, less emissions and lower costs has led to new developments. It was estimated that the fuel cell production has grown by $44 \%$ since 2014 - parallel to the increase in solar and wind energy in previous years. This rapid growth is driven by increased demand for energy diversification and the employment of alternative energy sources. Because of increased carbon emissions and extreme climatic events, businesses and communities demand three things: more affordable electricity, more durable power and cleaner energy.

The production of electricity as a result of an electrochemical reaction rather than fuel combustion shows that fuel cells are much cleaner and more sustainable than conventional combustion-dependent technology. Fuel cells are more environmentally friendly in two ways: first, they avoid spreading harmful impurities such as $\mathrm{NO}_{\mathrm{x}}$ and $\mathrm{SO}_{2}$, which are associated with respiratory diseases and poor air quality throughout the world, and the second they reduce greenhouse gas (GHG) emissions. Fuel cells are continually proving to be the most efficient, resilient, and sustainable form of alternative energy generation. As an energy solution that provides both sustainability and power security, fuel cells are the leading power generation technology for businesses and communities now and in the future.

A solid oxide fuel cell fueled with landfill gas has the potential to generate electrical energy, which seems to be an alternative to incineration and landfill applications. However, separating renewable hydrogen from biomass and landfill gas is not an easy task. Furthermore, construction and operation costs are quite high, which can cause customers to avoid risk. Today, those who started using solid oxide fuel cells early started to use government tax incentives and sustainability program grants.

Some of the systems that use direct fuel cells generally operate at $538^{\circ} \mathrm{C}$ and use biogas produced by anaerobic digesters. In most projects, the purified landfill gas can be injected into an existing natural gas pipeline that directs it to direct fuel cell units elsewhere. However, it is a fact that landfill gas contains moisture, sulfur and $\mathrm{CO}_{2}$. For landfill gas-fueled fuel cell systems, desulphurization and moisture removal is required, while stricter pipeline quality is required for bio $\mathrm{H}_{2}$, thus $\mathrm{CO}_{2}$ must be removed for directed biogas systems.

\section{Conclusions}

Nickel-based anodes are suitable for SOFC technology when hydrogen gas is used as fuel. Biogas-SOFC energy system, which uses landfill gas as a feed source, can meet both electrical and thermal energy needs for homes away from the grid. However, the obligation to clean up biogas can have a major impact on the total investment and operating costs and thus complicate the procurement of technology among non-rural communities. Therefore, the choice of a cleaning system technology, in particular for the small-scale biogas-SOFC energy system, should also meet the impurity levels required by SOFC, typically less than $2 \mathrm{ppm}$ for $\mathrm{H}_{2} \mathrm{~S}$. For small-scale biogas-SOFC systems, a suitable gas cleaning unit must be very efficient to maintain low pollution levels and also economical for small-scale systems.

In this study direct landfill gas SOFC operation using landfill gas was successfully conducted on anode electrolyte and cathode materials of NiO-YSZ composite powder and LSM at $775^{\circ} \mathrm{C}$. This study showed that direct electro-oxidation of landfill gas in SOFCs has a great potential. SOFCs can provide intrinsically higher efficiencies than steam engines. It is very clear that SOFCs can offer many advantages for landfill gas conversion to electrical energy.

\section{References}

1. A.B. Stambouli, E. Traversa, Solid oxide fuel cells (SOFCs): a review of an environmentally clean and efficient source of energy. Renew. Sust. Energ. Rev. 6, 433-455 (2002)

2. Q.M. Nguyen, Ceramic Fuel Cells. J. Am. Ceram. Soc. 76, 563-588 (1993)

3. S.M. Haile, Materials for fuel cells, Mater. Today 6 , 24-29 (2003)

4. W.Z. Zhu, S.C. Devi, Development of interconnect materials for solid oxide fuel cells. Mat. Sci. Eng. R. 348, 227-243 (2003)

5. S.C. Singhal, Solid oxide fuel cells for stationary, mobile, and military applications. Solid State Ion. 152-153, 405-410 (2002)

6. N.M. Sammes, Y. Du, The mechanical properties of tubular solid oxide fuel cells. J. Mater. Sci. 38, 48114816 (2003)

7. W.L. Lungberg, S.E. Veyo, M.D.A. Moeckel, HighEfficiency SOFC Hybrid Power System Using the Mercury 50 ATS Gas Turbine. ASME Turbo Expo 2001: Power for Land, Sea, and Air Volume 2: Coal, Biomass and Alternative Fuels; Combustion and 
Fuels; Oil and Gas Applications; Cycle Innovations, New Orleans, Louisiana, USA (2001)

8. M.C. Williams, P.S. Strakey, W.A. Surdoval, L.C. Wilson, Solid oxide fuel cell technology development in the U.S., in Solid State Ionics 15: Proceedings of the 15th International Conference on Solid State Ion, Part I, 177, pp. 2039-2044 (2006)

9. J. Mirzababaei, S.S.C. Chuang, $\mathrm{La}_{0.6} \mathrm{Sr}_{0.4} \mathrm{Co}_{0.2} \mathrm{Fe}_{0.8} \mathrm{O}_{3}$ Perovskite: A Stable Anode Catalyst for Direct Methane Solid Oxide Fuel Cells. Catalysts 4(2), 146161 (2014). doi:10.3390/catal4020146

10. L. Jiang, A. B. Scott, Operation of anode-supported solid oxide fuel cells on methane and natural gas. Solid State Ion 158(1-2), 11-16 (2003)

11. Y. Hongxin, G. Hongjie, C. Gang, A. Abuliti, D. Xinwei, The conversion among reactions at Ni-based anodes in solid oxide fuel cells with low concentrations of dry methane. J. Power Sources 196(5), 2779-2784 (2011)

12. A.B. Marco, M.H. Josephine, Methane Electrochemical Oxidation Pathway over a Ni/YSZ and $\mathrm{La} 0.3 \mathrm{Sr} 0.7 \mathrm{TiO} 3 \mathrm{Bi}-\mathrm{Layer}$ SOFC Anode. J. Electrochem. Soc. 159, 361 (2012)

13. K. Nikooyeh, R. Clemmer, V. Alzate-Restrepo, J.M. Hill, Effect of hydrogen on carbon formation on $\mathrm{Ni} / \mathrm{YSZ}$ composites exposed to methane. Appl. Catal. A Gen. 347, 106-111 (2008)

14. J. Kuhn, O. Kesler, Method for in situ carbon deposition measurement for solid oxide fuel cells. J Power Sources 246, 430-437 (2014)

15. Z. Tao, G. Hou, N. Xu, Q. Zhang, A highly cokingresistant solid oxide fuel cell with a nickel doped ceria: Ce1_xNixO2_y reformation layer. Int. J. Hydrogen Energy 3(9), 5113-5120 (2014)

16. C. Selahattin, A. Mahmut, Experimental Investigation of Fuel Utilization in Solid Oxide Fuel Cell. OHU J. Eng. Sci. 7(2), 966-978 (2018) 